\title{
Biodegradation of Chlorpyrifos (CP) by a Newly Isolated Naxibacter sp. Strain CY6 and Its Ability to Degrade CP in Soil
}

\author{
Chul Ho Kim ${ }^{1,2}$, Jin Sang Choi ${ }^{1,3}$, In Surk Jang ${ }^{1,4}$, and Kye Man Cho ${ }^{1,3 *}$ \\ ${ }^{1}$ Institute of Fusion Biotechnology, ${ }^{2}$ Department of Pharmaceutical Engineering, \\ ${ }^{3}$ Department of Food Science, ${ }^{4}$ Department of Animal Science and Biotechnology, \\ Gyeongnam National University of Science and Technology, Jinju 660-758, Republic of Korea
}

\section{신규 Naxibacter sp. CY6에 의한 Chlorpyrifos (CP) 분해 및 토양에서 $\mathrm{CP}$ 분해능}

\author{
김철호 ${ }^{1,2} \cdot$ 최진상 ${ }^{1,3} \cdot$ 장인석 $^{1,4} \cdot$ 조계만 ${ }^{1,3 *}$ \\ ${ }^{1}$ 경남과학기술대학교 바이오융합연구소, ${ }^{2}$ 경남과학기술대학교 제약공학과, \\ ${ }^{3}$ 경남과학기술대학교 식품과학부, ${ }^{4}$ 경남과학기술대학교 동물생명과학과
}

(Received February 21, 2013 / Accepted March 22, 2013)

\begin{abstract}
A bacterium, isolated from a vegetable field in a plastic film house and named strain CY6 was capable of biodegrading chlorpyrifos (CP). Based on the phenotypic features and the phylogenetic similarity of 16S rRNA gene sequences, strain CY6 was identified as a Naxibacter sp. CP was utilized as the sole source of carbon and phosphorus by Naxibacter sp. CY6. We examined the role of this Naxibacter sp. in the degradation of other OP insecticides under liquid cultures. Parathion, methyl parathion, diazinon, cadusafos, and ethoprop could also be degraded by Naxibacter sp. CY6 when they are provided as the sole sources of carbon and phosphorus. Additionally, Naxibacter sp. CY6 $\left(10^{8} \mathrm{CFU} / \mathrm{g}\right)$ added to soil with CP $(100 \mathrm{mg} / \mathrm{kg})$ resulted in a higher degradation rate of approximately $90 \%$ than the rate obtained from uninoculated soils. These results highlight the potential of this bacterium to be used in the cleanup of contaminated pesticide soil.
\end{abstract}

Keywords: $\beta$-proteobacteria, Naxibacter sp. CY6, biodegradation, chlorpyrifos, organophosphours pesticides

Pesticides were introduced to agriculture to fulfill the increased food needs of the growing global population. With the restricted use of most of the organochlorinated (OC) insecticides, including dichloro-diphenyl-trichloroethane (DDT) and hexachlorcyclohexan $(\mathrm{HCH})$, due to their long persistence in the environment organophosphorus (OP) insecticides have accounted for the majority of insecticides consumption (Sardar and Kole, 2005). Although OP insecticides degrade faster than OC insecticides, this class of pesticides has acute neurotoxicity which is due to their ability to suppress acetylcholine esterase (AChE) (Anwar et al., 2009). OP poisoning is a worldwide health problem, with approximately three million poisonings and 200,000 deaths annually. OP insecticides are potent AChE inhibitors that have $50 \%$ lethal doses betweens 4 to 13 and 14

*For correspondence. E-mail: kmcho@gntech.ac.kr; Tel.: +82-55-7513272; Fax: +82-55-751-3279 to $24 \mathrm{mg} / \mathrm{kg}$ of mammalian body mass (Cho et al., 2009).

Chlorpyrifos $\left(\mathrm{C}_{9} \mathrm{H}_{11} \mathrm{C}_{13} \mathrm{NO}_{3} \mathrm{PS}\right)$ [CP; O,O-diethyl-O-(3,5,6trichloro-2-pyridyl) phosphorothioate, a phosphorothioate insecticide] is a broad spectrum systemic phosphorothioate ester insecticide that was patented and introduced by Dow Chemical Company in the USA in 1965, particularly for the control of foliar insects on grain, cotton, fruit, paddy fields, pasture and vegetable crops (Sardar and Kole, 2005; Cho et al., 2009; Maya et al., 2011). The half-life of CP in soil is usually between 60 and 120 days, but it can range from 2 weeks to over 1 year, depending on both chemical hydrolysis and microbial activity. In most cases, aerobic bacteria tend to hydrolyze CP to produce diethylthiphosphoric acid (DEPT) and 3,5,6-trichloro-2-pyridinol (TCP) (Anwar et al., 2009; Cho et al., 2009).

The microbial degradation of OP insecticides is of particular interest because of the high mammalian toxicity of such compounds and their widespread and extensive use (Islam et 
al., 2010). The CP or OP insecticides degrading bacteria was isolated previously (Sethunathan and Yoshida, 1973; Shelton, 1988; Rani and Lalitha-Kumari, 1994; Singh et al., 2004; Yang et al., 2005, 2006; Zhang et al., 2005, 2006; Li et al., 2007; Xu et al., 2008; Anwar et al., 2009; Cho et al., 2009; Wang et al., 2012) but this is the first report of OP insecticides degradation by Naxibacter species. In addition, the several researchers has identified the various genes (opd) and enzymes (OP hydrolase) involved in degradation of OP insecticides (Fu et al., 2004; Liu et al., 2005; Zhang et al., 2006; Li et al., 2007; Yang et al., 2008; Islam et al., 2010). Previous studies showed that OP contains phosphoric acid esters that can be hydrolyzed and detoxified by carboxylesterase and phophotriesterase (Islam et al., 2010).

In general, OP insecticides degradation in soil can be influenced by both biotic and abiotic factors, which act in tandem and complement one another in the microenvironment. Microbial activity has been deemed the most influential and significant cause of OP insecticides removal (Yang et al., 2005). Kertesz et al. (1994) suggested that the conditions under which the environmental isolates were enriched were crucial in selecting for strains with not only the desired degradative enzyme systems, but also specific regulation mechanisms for the degradation pathways. Larger microbial populations can exist in rhizosphere soil than in bulk soil; these larger populations have been shown to increase the degradation of organic chemicals including OP insecticides (Molina et al., 2000; Yang et al., 2005).

In the present study, the bacterium Naxibacter sp. CY6, which is capable of degrading not only $\mathrm{CP}$ but also parathion, methyl parathion, diazinon, cadusafos, and ethoprop, was isolated. The study aims at elucidating a possible application of the isolated bacterial strain for the biodegradation of $\mathrm{OP}$ contaminated soil.

\section{Materials and Methods}

\section{Chemicals, regents and media}

All reagents used in the present study were of analytical grade and were used without further purification. Cadusafos (CS; $S, S$-di-sec-butyl $O$-ethyl-phosphorodithioate), chlorpyrifos (CP; O,O-diethyl-O-3,5,6-trichloro-2-pyridinyl phosphorothioate), diazinon (DZ; O-3-chloro-4-methyl-2-oxo-2H-1-chromen-7-yl $O, O$-diethyl phosphorothioate), dyfonate (DF; $O$-ethyl $S$-phenyl ethylphosphonodithioate), ethoprop (EP; $O$-ethyl $S, S$-dipropyl phosphorodithioate), methyl parathion (MPT; O,O-dimethyl $O$-4-nitrophenyl phosphorothioate), and parathion (PT; $O, O$-diethyl $O$-4-nitrophenyl phosphorothioate) were obtained from ChemService (USA) and 3,5,6-trichloro-2-pyridinol (TCP) and diethylthiophosphate (DETP) were purchased from Sigma-Aldrich Chemical Co. (USA). HPLC-grade water, methanol, acetonitrile, and glacial acetic acid were purchased from Fisher Scientific (USA). TSA was obtained from Difco Co. (USA) and used in a solid culture. A mineral salt medium supplemented with nitrogen (MSMN) was modified and used in a liquid culture (Cho et al., 2009).

Isolation of a chlorpyrifos-degrading bacterium by enrichment culture

A mineral salt medium supplemented with nitrogen (MSMN) was used in both enrichment culture of pretreated soils and the liquid culture of isolated bacteria (Zhang et al., 2006). CP was dissolved in HPLC-grade acetone as a stock solution and added to MSMN. When the HPLC-grade acetone evaporated completely, it provided the desired pesticide concentration in MSMN. Soil samples $(10 \mathrm{~g})$ from the pesticide-contaminated soil of a green house were used to inoculate Erlenmeyer flasks $(250 \mathrm{ml})$ containing $50 \mathrm{ml}$ of MSMN with CP $(50 \mathrm{mg} / \mathrm{L})$ as the sole carbon source. Flasks were incubated at $30^{\circ} \mathrm{C}$ on a shaker at $160 \mathrm{rpm}$ in the dark for 5 days. Approximately $1 \mathrm{ml}$ of the suspension was then transferred to fresh MSMN containing $100 \mathrm{mg} / \mathrm{L} \mathrm{CP}$ and incubated for 5 days. After three rounds of enrichment, the culture was diluted with sterilized $0.1 \mathrm{M}$ phosphate buffer ( $\mathrm{pH}$ 7.5) through a dilution series. The $10^{-5}-$ to $10^{-8}$-diluted suspensions were plated on MSMN agar with CP $(100 \mathrm{mg} / \mathrm{L})$. After 5 days of incubation at $30^{\circ} \mathrm{C}$, microbial colonies became visible, and a clear halo appeared around colonies capable of degrading CP. We selected and purified these colonies and tested their degrading capability through inoculation in liquid medium (50 $\mathrm{ml}$ in a $250 \mathrm{ml}$-Erlenmeyer flask). Strain CY6, which degraded CP rapidly, was selected for further analysis.

\section{Identification of strain CY6}

The cell morphology was examined by light microscopy after Gram staining. The flagellum type was determined by transmission electron microscopy (TEM 1010; Jeol, USA) using preparations that were negatively stained with $1 \%$ phosphotungstic acid. The 16S rDNA of strain CY6 was amplified by PCR. The forward primer was 5 -TTCTACGGAG AGTTTGATCC- $3^{\prime}$ and the reverse primer was $5^{\prime}$-CACCTTCC GGTACGGCTACC-3'. Samples for nucleotide sequencing were prepared with the dideoxy-chain termination method using the PRISM Ready Reaction Dye terminator/primer cycle sequencing kit (Perkin-Elmer Corp., USA). The samples were analyzed with an automated DNA sequencer (Applied Biosystems, USA). The nucleotide sequences were assembled with the DNAMAN analysis system (Lynnon Biosoft, Canada). The 16S rDNA sequence of strain CY6 was aligned with that of other bacterial species obtained from the GenBank database. The 16S rDNA 
similarity values were calculated from the alignments, and evolutionary distances were calculated. The sequence of Naxibacter sp. CY6 was deposited in the GenBank database under the accession number JX987079.

\section{Inoculum preparation for degradation studies}

Strain CY6 was pre-cultured in Erlenmeyer flasks containing $50 \mathrm{ml}$ of MSMN supplemented with $100 \mathrm{mg} / \mathrm{L} \mathrm{CP}$. The flasks were incubated overnight at $30^{\circ} \mathrm{C}$ on a shaker at $160 \mathrm{rpm}$ in the dark. The contents of the inoculated flasks containing medium and CP were centrifuged, and the cell pellet was washed four times with fresh medium and quantified by the dilution plate count technique. For all experiments, the strain CY6 cells $\left(10^{8}\right.$ $\mathrm{CFU} / \mathrm{ml}$ ) were used, and samples were incubated at $30^{\circ} \mathrm{C}$ on a shaker at $160 \mathrm{rpm}$, unless otherwise stated.

\section{Growth and degradation of $\mathrm{CP}$, TCP and DEPT in liquid medium}

A volume of $250 \mu \mathrm{l}$ of bacterial culture suspension $\left(10^{8}\right.$ $\mathrm{CFU} / \mathrm{ml}$ ) was inoculated into $50 \mathrm{ml}$ of MSMN supplemented with CP, TCP and DEPT (100 mg/L). Periodically, an individual flask was analyzed to determine the growth and degradation of CP. Cultures were grown in triplicate to ensure accuracy. Growth was monitored by spectrophotometer at 600 $\mathrm{nm}$ (Spectronic 2D, Thermo Electron Co., USA). Escherichia coli $\mathrm{DH} 5 \alpha$ grown with $\mathrm{CP}$ and TCP $(100 \mathrm{mg} / \mathrm{L})$ was used as a control to investigate whether if the CP-degrading isolate could use CP, TCP, and DEPT as the sole source of carbon and phosphorus.

\section{Substrate range}

Cross-feeding studies with other OP insecticides were also performed. The liquid medium was supplemented with CS, DF, DZ, EP, MPT, or PT at $100 \mathrm{mg} / \mathrm{L}$. The growth of strain CY6 was tested on methanol, ethanol, propanol, isopropanol, and acetone using MSMN medium with one of these compounds as the sole source of carbon.

\section{Inoculation and degradation in soil}

The soil used for the pot culture experiments was collected from a depth of approximately $0-15 \mathrm{~cm}$ in a vegetable field in a plastic film house at Gyeongnam Agricultural Research and Extension Services, Chinju, Gyeongnam, Republic of Korea. The physical properties of the soil were $\mathrm{pH} 7.8$ and EC 0.85 $\mathrm{ds} / \mathrm{m}$, and the chemical properties of the soil were $24 \mathrm{~g} / \mathrm{kg}$ organic matter, $1198 \mathrm{mg} / \mathrm{kg} \mathrm{P}_{2} \mathrm{O}_{5}, 0.61 \mathrm{cmolc} / \mathrm{kg} \mathrm{K}, 13.21$ cmolc/kg Ca, 4.37 cmolc/kg Mg, 0.08 cmolc/kg Na, 27.3 $\mathrm{mg} / \mathrm{kg} \mathrm{NH} 4-\mathrm{N}$, and $9.7 \mathrm{mg} / \mathrm{kg} \mathrm{NO}_{3}-\mathrm{N}$. Soil samples $(1 \mathrm{~kg}$ ) were sterilized by fumigation with chloroform for 10 days at $30^{\circ} \mathrm{C}$.
Similar soil samples were stored at $4{ }^{\circ} \mathrm{C}$ in sealed polyethylene bags. Residual chloroform was removed from the fumigated soils by repeat evacuation in a vacuum desiccator. Subsamples $(100 \mathrm{~g})$ of the fumigated and nonfumigated soil were treated under aseptic conditions with $\mathrm{CP}(100 \mathrm{mg} / \mathrm{kg})$. One set of fumigated and nonfumigated soils in triplicate was inoculated with the CP-degrading bacterium $\left(10^{8} \mathrm{CFU} / \mathrm{g}\right)$, and another set without inoculation was kept as controls. The inoculum was thoroughly mixed into soils under sterile conditions. Soil samples were incubated at $30^{\circ} \mathrm{C}$ and $40 \%$ of water-holding capacity in the dark.

\section{Chemical extraction and analysis}

The method described by Cho et al. (2009) was modified to extract and analyze OPs from liquid culture and soil samples. For the analysis, $10 \mathrm{ml}$ of the liquid culture was collected and centrifuged and soil from planted pots was carefully collected, mixed, air dried and stored at $4{ }^{\circ} \mathrm{C}$ prior to usage in the experiment. In total, $5 \mathrm{ml}$ of supernatant or $5 \mathrm{~g}$ of dried soil was extracted with ethylacetate $(10 \mathrm{ml} \times 3)$, and the organic layer was dried with $\mathrm{Na}_{2} \mathrm{SO}_{4}$, and concentrated under a vacuum and dissolved in $5 \mathrm{ml}$ of HPLC-grade methanol.

The extracted samples were spotted on a pre-coated silica gel aluminum plate $(0.25 \mathrm{~mm}$, Merck, Germany). The TLC plate was developed with a chloroform and hexane $(4: 1, \mathrm{v} / \mathrm{v})$ solvent system for the detection of $\mathrm{CP}$. An ethylacetate, isopropanol, and $\mathrm{NH}_{4} \mathrm{OH}(5: 3: 2, \mathrm{v} / \mathrm{v})$ system was used for the detection of TCP. Finally, the target compounds were detected with UV (254 nm). In TLC, TCP was confirmed as the spot with an $R f$ value of approximately 0.66 , and the more polar CP was determined as the spot with an $R f$ value of approximately 0.57 .

The extract sample was filtered through a $0.45 \mu \mathrm{m}$ Minipore PVDF filter (Schleicher \& Schuell, GmbH, Germany) for HPLC analysis. The injection volume was $10 \mu \mathrm{l}$ of filtered sample. OP and TCP were analyzed with HPLC (HPLC, Perkin-Elmer 200 series, Perkin-Elmer Co., USA) using a C18 column $(250 \times 4.6 \mathrm{~mm}, 5 \mu \mathrm{m}$, Phenomenx, USA). A mixture of $0.5 \%$ acetic acid and methanol $(1: 4 \mathrm{v} / \mathrm{v})$ was eluted with a flow rate of $1 \mathrm{ml} / \mathrm{min}$ at $30^{\circ} \mathrm{C}$. The target, OP and TCP, compounds were measured at $214 \mathrm{~nm}$ with UV detector (Perkin-Elmer UV 200 series, Perkin-Elmer Co.). In HPLC analysis, TCP was detected at approximately $5.5 \mathrm{~min}$, and OPs were detected between 4.6 and $14.0 \mathrm{~min}$, depending on the feature of the each functionality.

\section{Results}

Isolation and identification of chlorpyrifos degrading bacterium

Using the enrichment cultivation approach, we isolated the 
bacterial strain $\mathrm{CY} 6$ that could utilize $\mathrm{CP}$ as the sole carbon and energy source. The CY6 colony was yellow, rough, irregular, and raised after 4 to 5 days of growth on TSA. The cells are Gram negative and rod-shaped, motile, one polar flagella, and measuring $0.7-1.0 \times 2.8-5.4 \mu \mathrm{m}$ in after $12 \mathrm{~h}$ culture on TSB at $30^{\circ} \mathrm{C}$ (Fig. 1). A phylogenetic tree constructed from the sequence data showed that strain CY6 grouped within the evolutionary radiation, which grouped within the $\beta$-proteobacteria class, and it occupied a distinct phylogenetic position within $\beta$ -proteobacteria. The level of $16 \mathrm{~S}$ rDNA similarity between strain CY6 and $\beta$-proteobacteria ranged from 88.4 to $98.0 \%$. The highest 16S rDNA sequence similarity (98.0\%) was observed between strain CY6 and Naxibacter alkalitolerans YIM31775. This phylogenetic study clearly establishes that
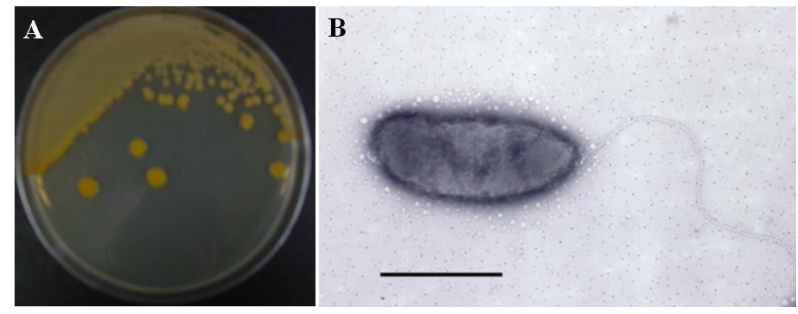

Fig. 1. The colony morphologies of strain CY6 (A) and transmission electron micrograph of strain CY6 from exponentially growing culture (B). (A) The organism was grown on TSA at $30^{\circ} \mathrm{C}$ for 5 days. (B) Scale bar, $1.4 \mu \mathrm{m}$.

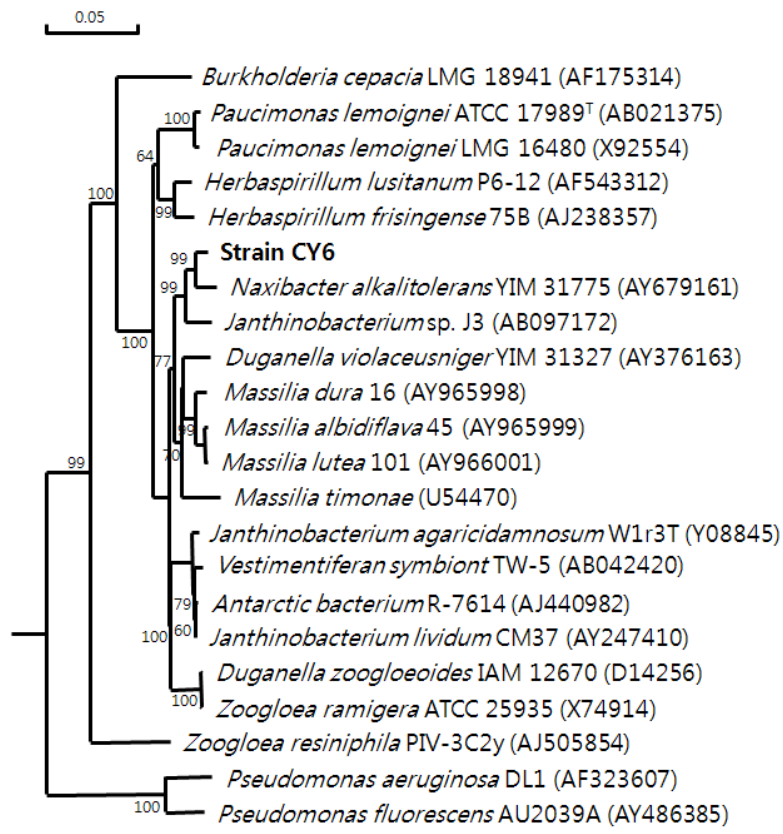

Fig. 2. Phylogenetic tree based on the 16S rDNA gene sequences of strain CY6. Bootstrp values obtained with 1,000 repetitions were indicated as percentages at all branches. GenBank accession nos. are given in brackets. strain CY6 is closely related to Naxibacter sp. (Fig. 2).

\section{Degrading ability of Naxibacter sp. CY6}

Naxibacter sp. CY6 was able to degrade CP as the sole source of carbon into diethyl thiophosphate (DETP) and TCP. The TLC results are shown in Fig. 3, CP and TCP, with $R f$ values of 0.57 and 0.66 , respectively, were detected in samples collected at 0,2 , and 6 days. The samples collected after 6 days of growth did not show the presence of CP but showed the presence of TCP. CP was almost completely degraded within 6 days. Within 2 days, Naxibacter sp. CY6 exhibited an initial rapid degradation of $\mathrm{CP}$ of approximately $35 \mathrm{mg} / \mathrm{L} \mathrm{CP}$. The rate then slowed to $3-10 \mathrm{mg} / \mathrm{L} \mathrm{CP}$, eventually leading to $92 \%$ CP degradation (Fig. 4). All OP insecticides tested in the cross-feeding experiment were degraded by strain CY6 (Fig. 5). Some of tested OP insecticides had DEPT side chains (PT, MPT, and DZ), and some did not have DEPT (DF, EP, and CD) side chains. Except for DF, five of the OP insecticides (PT, MPT, DZ, EP, and CD) were hydrolyzed at a phosphoester bond by Naxibacter sp. CY6. Specifically, after 6

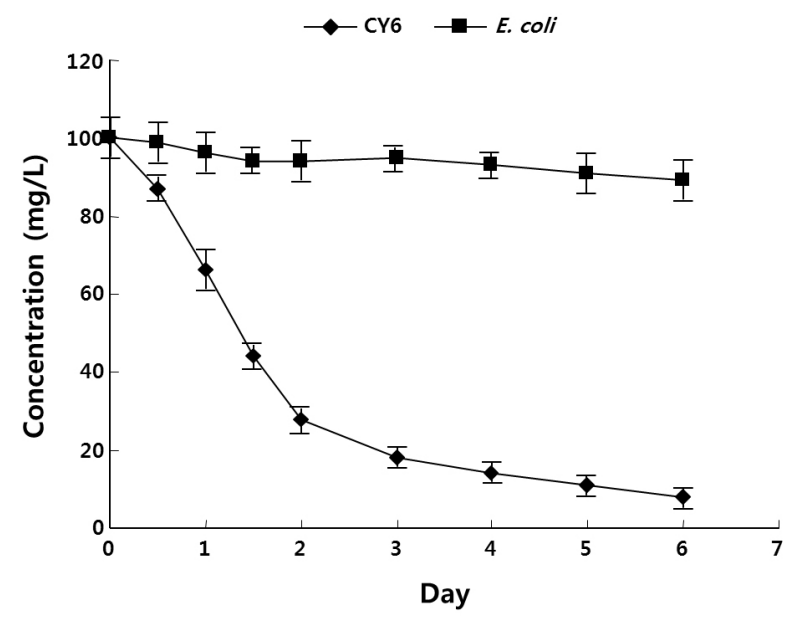

Fig. 3. Degradation of CP (B) during E. coli $\mathrm{DH} 5 \alpha$ and the strain CY6 growth on MSMN contained in CP. The standard errors were within $5 \%$ of the mean. Values are means \pm SD of three replicates.

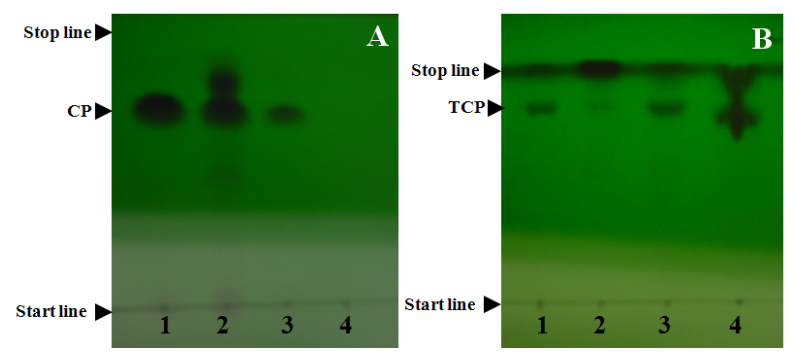

Fig. 4. CP (A) and TCP (B) TLC profiles during the strain CY6 growth on MSMN contained in CP. Lanes: 1, CP and TCP standard; 2, 0 day; 3, 2 day; 4, 6 day. 
days, the degradation of PT and MPT was 69 and $68 \%$, respectively.

\section{Inoculation of Naxibacter sp. CY6 into soil and the degradation of chlorpyrifos}

The addition of Naxibacter sp. CY6 to vegetable field soils from a plastic film house resulted in a more rapid rate of $\mathrm{CP}$ degradation than indigenous microflora. A significant difference in CP degradation was observed in soil with different treatments. The efficiency of degradation in nonfumigated soil was generally better than in fumigated soil. The degradation of $\mathrm{CP}$ in control fumigated soil and nonfumigated soil without inoculation was minimal, and less than $30 \%$ of the applied concentration was degraded in 30-day incubation studies. The degradation of CP in control fumigated soil and nonfumigated soil with inoculation was higher than $90 \%$ of the applied concentration in 30-day incubation studies. Within the 12 days, the degradation of $\mathrm{CP}$ in control fumigated soil and nonfumigated soil with inoculation was initially rapid with approximately 19 and $21 \mathrm{mg} / \mathrm{L} \mathrm{CP}$, respectively, degraded at 3 days (Fig. 6).

\section{Discussion}

In this study, CP degrading isolates were obtained from the vegetable field in plastic film house at Gyeongnam Agricultural Research and Extension Services, Chinju, Gyeongnam, Republic of Korea. The isolate CY6 was identified through

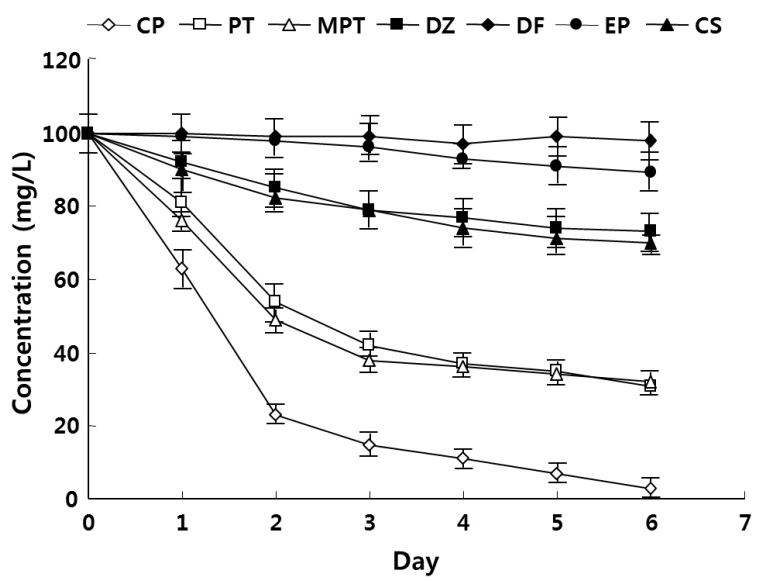

Fig. 5. Degradation of different organophosphate insecticides during strain CY6 growth on MSMN contained in CP, PT, MPT, DZ, EP, and CD. The standard errors were within $5 \%$ of the mean. chlorpyrifos (CP, white diamond symbols); parathion (PT, white square symbols), methyl parathion (MPT, white triangle symbols), ethoprop (EP, black circle symbols), diazinon (DA, black square symbols), cadusafos (CD, black triangle symbols), dyfonate (DF, black diamond symbols). The standard errors were within $5 \%$ of the mean. Values are means \pm SD of three replicates. sequencing of the $16 \mathrm{~S}$ rRNA gene. The isolate selected for further study, strain CY6, showed the greatest similarity to members of the $\beta$-proteobacteria class, and in particularly Naxibacter sp.. The Naxibacter genus has been reported as chemo-organotrophic bacteria (Xu et al., 2005). However, this is the first report of CP degradation by Naxibacter species. This bacterium is unusual because it was shown to hydrolyze $\mathrm{CP}$ and utilized part of the compound (DEPT) as its sole source of carbon. This bacterium is unusual because it was shown to hydrolyze CP and utilized part of the compound (DEPT) as its sole source of carbon but not utilized part of TCP. The evidence from the analysis of CP with TLC and HPLC supports the proposed pathway. A higher bacterial population of Naxibacter sp. CY6 was observed in MSMN with CP, and CP was degraded faster.

Previous reports on the isolation of OP-degrading microorganisms suggest that the bacteria mainly degrade these compounds co-metabolically (Mulbry et al., 1986). Some species of bacteria that can utilize OP as a source of carbon or phosphorus have been isolated from hydrolysis products (Rosenberg and Alexander, 1979). A significant observation was the utilization of OP insecticides as a source of carbon and phosphorus by Naxibacter sp. CY6. In addition, Naxibacter sp. CY6 was capable of hydrolyzing five OP insecticides (PT, MPT, DZ, EP, and CS) but not DF. Naxibacter sp. CY6 exhibited versatility in utilizing dimethyl compounds such as MPT and diethyl compounds such as $\mathrm{CP}, \mathrm{PT}$, and $\mathrm{DZ}$ as its carbon source. They have diethyl (or dimethyl) phosphorothionate side

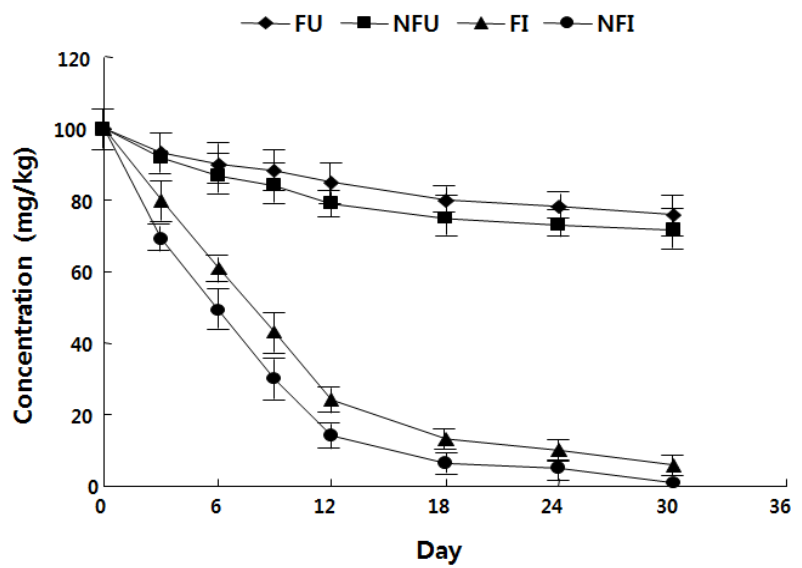

Fig. 6. Degradation of CP in soils inoculated with strain CY6 $\left(10^{8}\right.$ $\mathrm{CFU} / \mathrm{g}$ ) at fumigated soil and uninoculated, nonfumigated soil and uninoculated, fumigated soil and inoculated, and nonfumigated soil and inoculated. The standard errors were within $5 \%$ of the mean. Fumigated soil and uninoculated (diamond symbols); nonfumigated soil and uninoculated (square symbols); fumigated soil and inoculated (triangle symbols); nonfumigated soil and inoculated (circle symbols). The standard errors were within $5 \%$ of the mean. Values are means $\pm \mathrm{SD}$ of three replicates. 
chains, and there was a phosphotriester bond in all compounds, which may explain the reason for their degradation. Sethunathan and Yoshida (1973) isolated a Flavobacterium species that could use parathion as a source of phosphorus but not carbon from diazinon as a carbon source. However, the Flavobacterium strain was not able to use other OP insecticides as a source of phosphorus or carbon. Shelton (1988) isolated a consortium that could use diethylthiophosphoric acid as a carbon source but was unable to degrade it as a phosphorus or sulfur source.

In previously, the several researchers had identified OP insecticides degrading bacteria. For some OPs such as PT, it has been relatively easy to isolate degrading bacteria: two different strains, Flavobacterium sp. ATCC 27551 and Pseudomonas diminuta $\mathrm{Gm}$, have been isolated from soils in the Philippines and United States, respectively (Sethunathan and Yoshida, 1973; Shelton, 1988). Rani and Lalitha-Kumari (1994) found that Pseudomonas putida could hydrolyze methyl parathion and use $\rho$-nitrophenol as a sole source of carbon. Zhang et al. (2005) isolated seven MPT-degrading bacteria from soil that had long-term MPT contamination. Zhang et al. (2006) reported a fenitrothion-degrading strain, Burkholderia sp. FDS-1, from the sludge of a wastewater treatment system in an OP manufacturing company. Recently, Wang et al. (2012) isolated the MPT-degrading bacterium Agrobacgterium sp. Yw12 from activated sludge. Several effective CP-degrading strains have previously been described: Singh et al. (2004) identified the CP-degrading bacterium Enterobacter sp. B-14 from the soil. Yang et al. (2006) and Li et al. (2007) isolated the CP-degrading bacteria Stenotrophomonas sp. YC-1 and Sphingomonas sp. Dsp-2 from the sludge of a wastewater treatment system in an OP manufacturing company. Anwar et al. (2009) also reported the CP-degrading strains Bacillus pumilus C2A1. In addition, Yang et al. (2005) isolated Alcaligenes faecalis DSP3, which could degrade not only CP but also PT and DZ. Cho et al. (2009) also reported that four kimchi-lactic acid bacteria could degrade coumaphos, DZ, PT, MPT, and CP. Xu et al. (2008) isolated Paracoccus sp. TRP, which could degrade not only CP but also pyridine, MPT, and carbofuran when they were provided as the sole carbon and energy sources. Due to its broad specificity against a range of OP compounds, Naxibacter sp. CY6 possesses a high potential to provide a versatile gene or enzymes system that may be used for the remediation of highly toxic OP nerve agents.

The successful removal of OP insecticides in soil through the addition of bacteria had been previously reported, but (Singh et al., 2004; Yang et al., 2005, 2006; Li et al., 2007; Anwar et al., 2009). The degradation of high concentration of different pesticides by isolated microorganisms has been reported previously. One of the important reasons cited for the lack of isolation of CP-utilizing microorganisms is the antimicrobial activity of TCP at high concentrations (Racke et al., 1990). The growth of the isolated Naxibacter species was not affected by TCP, even at concentrations of higher than 250 $\mathrm{mg} / \mathrm{L}$. Naxibacter sp. CY6 isolated in this study did not degrade TCP. The results from the present study confirm that the isolated $\mathrm{CP}$-degrading bacterium could be used successfully for the removal of these pesticides from contaminated soil.

In conclusions, one CP-degrading isolate was obtained from a vegetable field in a plastic film house. We studied the role of Naxibacter sp. CY6, in the degradation of CP in liquid culture and in the soil. Microorganisms are a major component of the ecosystem and play a considerable role in the degradation of insecticides. Further investigations are in progress to identify the genes and enzymes involved in the degradation process. For practical application, further studies are needed to improve our understanding of the fate of $\mathrm{OP}$ insecticides in aquatic environments and soils.

\section{적 요}

채소 재배 비닐하우스 토양으로부터 chlorpyrifos $(\mathrm{CP})$ 분해 능을 지니고 있는 CY6 균주를 분리하였다. 형태학적 특징 및 $16 \mathrm{~S}$ rRNA 염기서열의 계통발생학적 유사성을 기초로 CY6 균 주는 Naxibacter sp.로 확인되었다. CP는 Naxibacter sp. CY6 의해 탄소 및 인의 단일원으로 이용되었다. 우리는 액체배양에 서 Naxibacter sp. CY6의 다른 OP 살충제 분해 양상을 살펴 보 았다. Naxibacter sp. CY6는 parathion 및 methyl parathion, diazinon, cadusafos, ethoprop를 분해할 수 있었으며, 이 때 이들 은 탄소 및 인의 단일원으로 제공되었다. 또한, $\mathrm{CP}(100 \mathrm{mg} / \mathrm{kg})$ 가 함유된 토양에 Naxibacter sp. CY6 $\left(10^{8} \mathrm{CFU} / \mathrm{g}\right)$ 를 접종한 것 이 접종하지 않은 토양에서 보다 약 $90 \%$ 의 높은 분해 정도를 나 타냈었다. Naxibacter sp. CY6는 살충제가 오염된 토양의 정화 에 사용할 수 있는 잠재성을 지니고 있다.

\section{Acknowledgements}

This study was supported by Royalties Program (Grant No. 10042317: Professional GLP training for the action against EU-REACH and FTA), Ministry of Knowledge Economy (MKE) and was partially supported by Institute of Fusion Biotechnology, Gyeongnam National University of Science and Technology, Republic of Korea.

\section{References}

Anwar, S., Liaquat, F., Khan, Q.M., Khalid, Z.M., and Iqbal, S. 2009. Biodegradation of chlorpyrifos and its hydrolysis product 3,5,6-trichloro-2-pyridinol by Bacillus pumilus strain C2A1. $J$. 
Hazard Mat. 168, 400-405.

Cho, K.M., Math, R.K., Islam, S.M.A., Lim, W.J., Hong, S.Y., Kim, J.M., Yun, M.G., Cho, J.J., and Yun, H.D. 2009. Biodegradation of chlorpyrifos by lactic acid bacteria during kimchi fermentation. $J$. Agric. Food Chem. 57, 1882-1889.

Fu, G., Cui, Z., Huang, T., and Li, S. 2004. Expression, purification, and characterization of novel methyl parathion hydrolase. Protein Expr. Purif. 36, 170-176.

Islam, S.M.D., Math, R.K., Cho, K.M., Lim, W.J., Hong, S.Y., Kim, J.M., Yun, M.G., Cho, J.J., and Yun, H.D. 2010. Organophosphorus hydrolase (OpdB) of Lactobacillus brevis WCP902 from kimchi is able to degrade organophosphorus pesticides. J. Agric. Food Chem. 58, 5380-5386.

Kertesz, M.A., Cook, A.M., and Leisinger, T. 1994. Microbial metabolism of sulfur and phosphorus-containing xenobiotics. FEMS Microbiol. Rev. 15, 195-215.

Li, X., He, J., and Li, S. 2007. Isolation of a chlorpyrifos-degrading bacterium, Sphingomonas sp. strain Dsp-2, and cloning of the $m p d$ gene. Res. Microbiol. 158, 143-149.

Liu, H., Zhang, J.J., Wang, S.J., Zhang, Z.E., and Zhou, N.Y. 2005. Plasmid-borne catabolism of methyl parathion and $p$-nitrophenol in Pseudomonas sp. strain WBC-3. Biochem. Biophys. Res. Commun. 334, 1107-114.

Maya, K., Shigh, R.S., Upadhyay, S.N., and Dubey, S.K. 2011. Kinetic analysis reveals bacterial efficacy for biodegradation of chlorpyrifos and its hydrolyzing metabolite TCP. Proc. Biochem. 46, 2130-2136.

Molina, L., Ramos, C., Duque, E., Ronchel, M.C., Garcia, J.M., Wyke, L., and Ramos, J.L. 2000. Survival of Pseudomonas putida KT2440 in soil and in the rhizophere of plants under greenhouse and environmental conditions. Soil Biol. Biochem. 32, 316-321.

Mulbry, W.W., Kams, J.S., Keamey, P.C., Nelson, J.O., McDaniel, C.S., and Wild, J.R. 1986. Identification of a plasmid-borne parathion hydrolase gene from Flavobacterium sp. by Southern hybridization with opd from Pseudomonas diminuta. Appl. Environ. Microbiol. 51, 926-930.

Racke, K.D., Laskowski, D.A., and Schultzon, M.R. 1990. Resistance of chlorpyrifos to enhanced biodegradation in soil. J. Agric. Food Chem. 38, 1430-1436.

Rani, N.L. and Lalitha-Kumari, D. 1994. Degradation of methyl parathion by Pseudomonas putida. Can. J. Microbiol. 4, 1000-1004.

Rosenberg, A. and Alexander, M. 1979. Microbial cleavage of various organophosphorus insecticides. Appl. Environ. Microbiol. 37, 886-
891.

Sardar, D. and Kole, R.K. 2005. Metabolism of chlorpyrifos in relation to its effect on the availability of some plant nutrients in soil. Chemosphere 61, 1273-1280.

Sethunathan, N.N. and Yoshida, T. 1973. A Flavobacterium that degrades diazinon and parathion. Can. J. Microbiol. 19, 873-875.

Shelton, D.R. 1988. Mineralization of diethylthiophosphoric acid by an enriched consortium form cattle dip. Appl. Environ. Microbiol. 54, 2572-2573.

Singh, B.K., Walker, A., Morgan, J.A.W., and Wright. D.J. 2004. Biodegradation of chlorpyrifos by Enterobacter strain B-14 and its use in bioremediation of contaminated soils. Appl. Environ. Microbiol. 70, 4855-4863.

Wang, S., Zhang, C., and Yan, Y. 2012. Biodegradation of methyl parathion and $p$-nitrophenol by a newly isolated Agrobacterium sp. strain Yw12. Biodegradation 23, 107-116.

Xu, P., Li, W.J., Tang, S.K., Zhang, Y.Q., Chen, G.Z., Chen, H.H., Xu, L.H., and Jiang, C.L. 2005. Naxibacter alkalitolerans gen. nov., sp. nov., a novel member of the family 'Oxalobacteraceae' isolated from China. Int. J. Syst. Evol. Microbiol. 55, 1149-1153.

Xu, G., Zheng, W., Li, Y., Wang, S., Zhang, J., and Yan, Y. 2008. Biodegradation of chlorpyrifos and 3,5,6-trichloro-2-pyridinol by a newly isolated Paracoccus sp. strain TRP. Int. Biodeterior. Biodegrad. 62, 51-56.

Yang, C., Liu, N., Guo, X., and Qiao, C. 2006. Cloning of $m p d$ gene from a chlorpyrifos-degrading bacterium and use of this strain in bioremediation of contaminated soil. FEMS Microbiol. Lett. 265, $118^{-125 .}$

Yang, J., Yang, C., Jiang, H., and Qiao, C. 2008. Overexpression of methyl parathion hydrolase and its application in detoxification of organophosphates. Biodegradation 19, 831-839.

Yang, L., Zhao, Y.H., Zhang, B.X., Yang, C.H., and Zhang, X. 2005. Isolation and characterization of a chlorpyrifos and 3,5,6-trichloro-2-pyridinol degrading bacterium. FEMS Microbiol. Lett. 251, 67-73.

Zhang, R., Cui, Z., Jiang, J., He, J., Gu, X., and Li, S. 2005. Diversity of organophophorus pesticide-degrading bacteria in a polluted soil and conservation of their organophosphorus hydrolase genes. Can. J. Micrboiol. 51, 337-343.

Zhang, Z., Hong, Q., Xu, J., Zhang, X., and Li, S. 2006. Isolation of fenitrothion-degrading strain Burkholderia sp. FDS-1 and cloning of mpd gene. Biodegradation 17, 275-283. 